\title{
HSD17B1 wt Allele
}

National Cancer Institute

\section{Source}

National Cancer Institute. HSD17B1 wt Allele. NCI Thesaurus. Code C104036.

Human HSD17B1 wild-type allele is located within 17q11-q21 and is approximately $4 \mathrm{~kb}$ in length. This allele, which encodes estradiol 17-beta-dehydrogenase 1 protein, plays a role in converting both estrogens and androgens to their active forms. 